2008

\title{
A Probable Early 19th Century Coushatta Village Site on Big Cypress Bayou in Northeastern Texas
}

Timothy K. Perttula

Heritage Research Center, Stephen F. Austin State University

Bryan E. Boyd

Follow this and additional works at: https://scholarworks.sfasu.edu/ita

Part of the American Material Culture Commons, Archaeological Anthropology Commons, Environmental Studies Commons, Other American Studies Commons, Other Arts and Humanities Commons, Other History of Art, Architecture, and Archaeology Commons, and the United States History Commons

Tell us how this article helped you.

This Article is brought to you for free and open access by the Center for Regional Heritage Research at SFA ScholarWorks. It has been accepted for inclusion in Index of Texas Archaeology: Open Access Gray Literature from the Lone Star State by an authorized editor of SFA ScholarWorks. For more information, please contact cdsscholarworks@sfasu.edu. 


\section{A Probable Early 19th Century Coushatta Village Site on Big Cypress Bayou in Northeastern Texas}

\section{Creative Commons License}

\section{(c) (1) \&}

This work is licensed under a Creative Commons Attribution-NonCommercial 4.0 International License 


\section{A PROBABLE EARLY $19^{\mathrm{TH}}$ CENTURY COUSHATTA VILLAGE SITE ON BIG CYPRESS BAYOU IN NORTHEASTERN TEXAS}

Timothy K. Perttula and Bryan E. Boyd

\section{INTRODUCTION}

In February 2002, avocational archaeologists from northeastern Texas and northwestern Louisiana conducted archaeological investigations in an area along Big Cypress Bayou in Marion County, Texas, to search for and identify a pre-1841 Coushatta Indian village depicted on a 1943 General Land Office map (General Land office 1941:304-305). That map (Figure 1a) showed a "Coushatti" village with at least seven to eight structures (a common way at the time to indicate an Indian village, but not necessarily an accurate characterization of the number of structures once present at the site) near the confluence of Black Cypress Bayou and Big Cypress Bayou. This article describes the results of these archaeological investigations.

Other Alabama (Alibamu) and Coushatta (Koasati) villages have been documented in recent years through archaeological and historical investigations in the Caddo Lake and Red River areas of northeastern Texas and northwestern Louisiana (Bagur 2001:54-58; McCrocklin 1990; Jurney and Perttula 1995). These villages were first established around 1803 or 1804 by these members of the Creek Indian confederacy who had moved or resettled as a group from the Alabama River area of east-central Alabama. The Alabama and Coushatta chose to resettle in traditional Caddo lands rather than "associate with the British and American traders and settlers who moved into Creek Territory after the French and Indian War, which ended in 1763, and the American Revolution" (Perttula 1994:66).

\section{ARCHAEOLOGICAL INVESTIGATIONS}

Permission was obtained from private landowners in the Big Cypress-Black Cypress bayou confluence area, concentrating on upland landforms east of Big Cypress Bayou (Figure 1b). These wooded uplands are $50 \mathrm{ft}$. or more in elevation above the swampy and marshy Big Cypress Bayou floodplain.

The archaeological investigations included two components: metal detector survey (and subsequent exploration of the metal detector find spot) and the excavation of three $1 \times 1 \mathrm{~m}$ units amidst the ca. $430 \mathrm{~m}^{2}$ area of metal detector hits. There were a total of 18 metal detector hits in this area (Figure 2). The site has been assigned site trinomial $41 \mathrm{MR} 254$. 


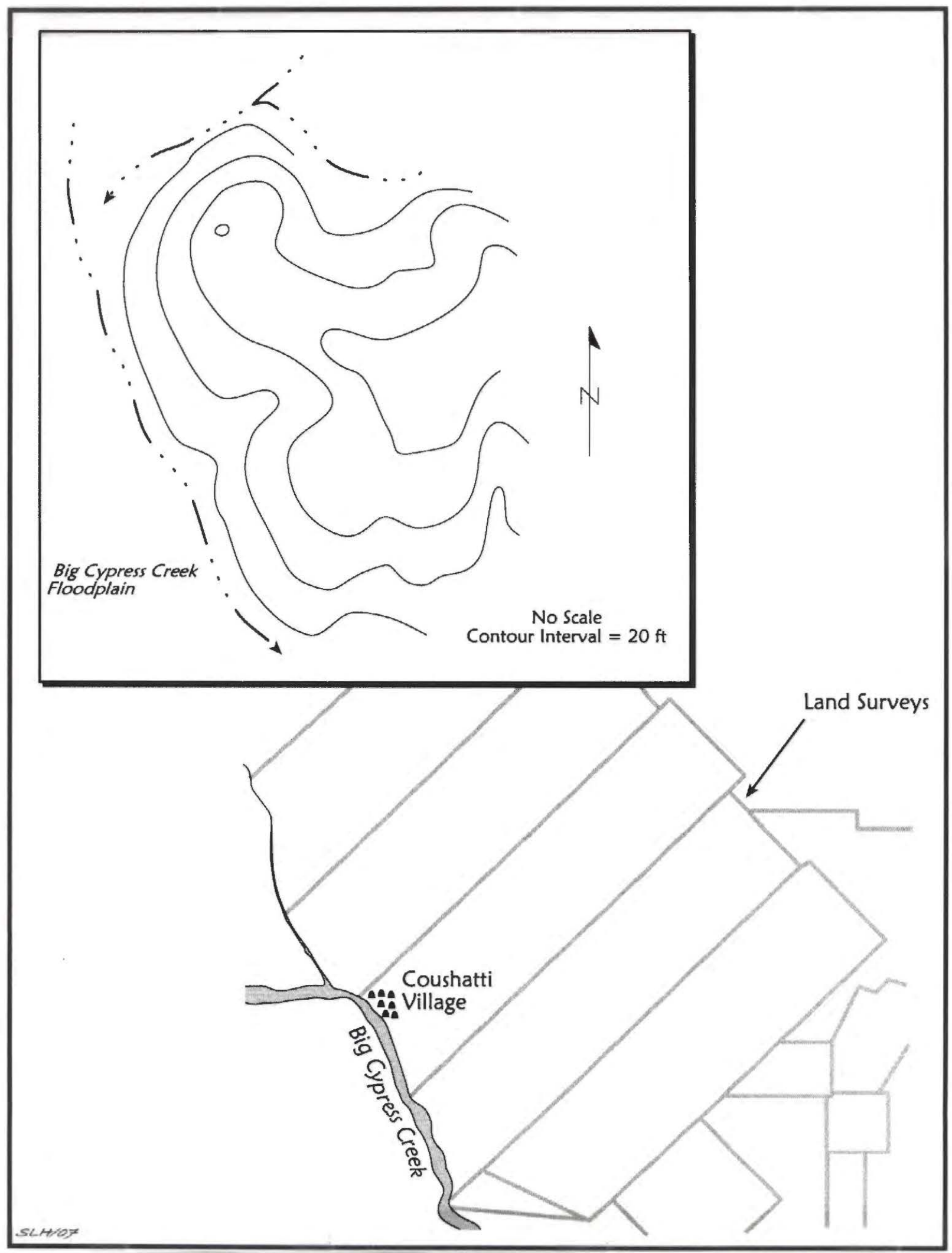

Figure 1. Coushatta village on Big Cypress Creek: a (lower), redrawn 1943 General Land Office map; b (upper) general topographic location of 41MR254. 


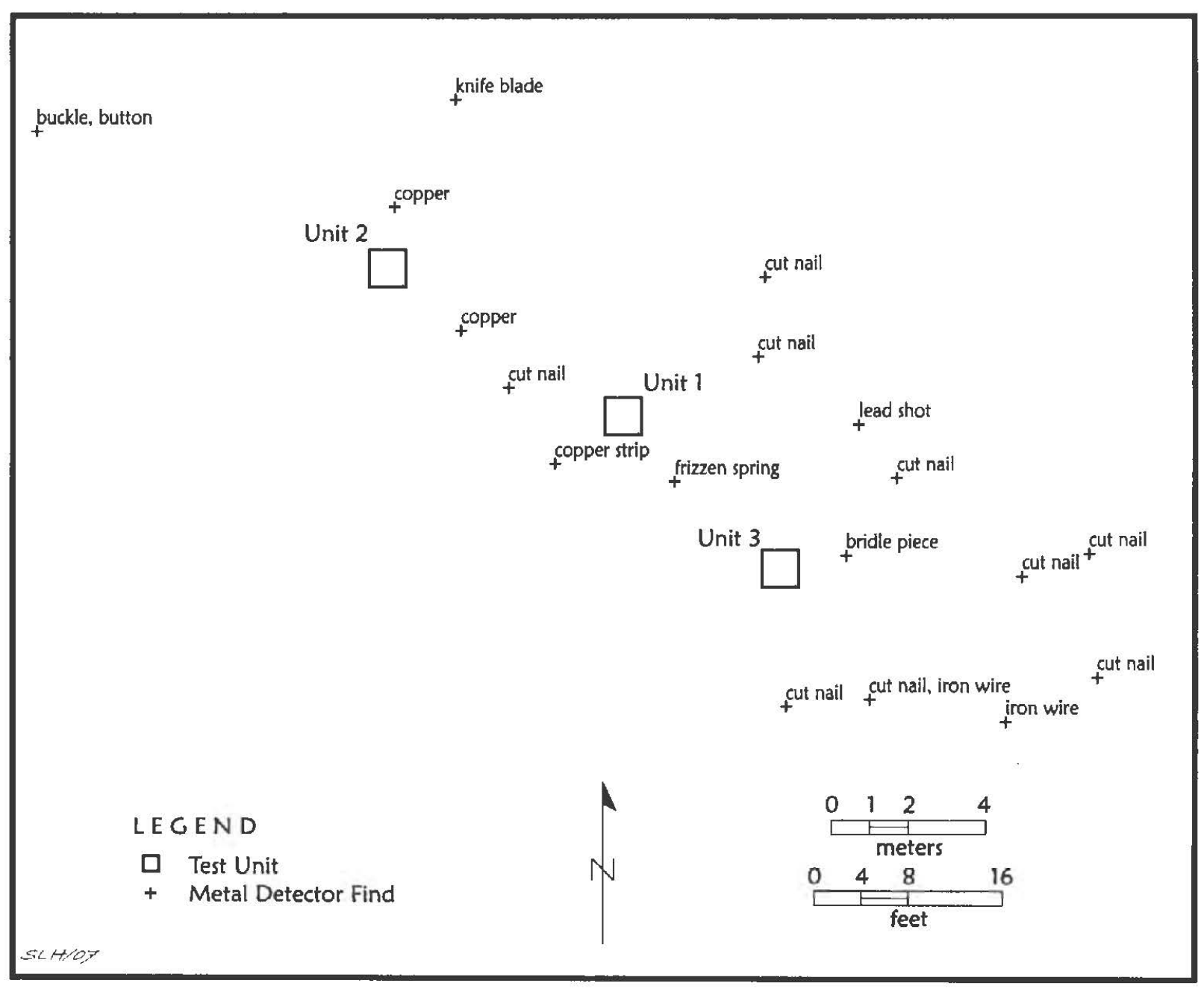

Figure 2. Investigations and metal detector find spots at 41MR254. 
In the three units, archaeological materials were recovered in the 1/4-inch screening of dark brown sandy loam sediments to only $10 \mathrm{~cm}$ bs; these sediments are very gravelly. The units were eventually excavated to between $17-20 \mathrm{~cm}$ bs, but these lower sediments did not contain any archaeological remains. No features were identified in the three excavation units.

\section{ARCHAEOLOGICAL MATERIALS FROM 41MR254}

Because of the limited archaeological work conducted at 41MR254 in 2002, only a small sample of artifacts were recovered in the metal detecting and unit excavations (Table 1). This includes 16 aboriginal ceramic sherds, three pieces of lithic debris, and 28 pieces of metal. One piece of metal-a Western No. 12, Super X shot gun shell-is much younger than the remainder of the metal, and it is not associated with the early $19^{\text {th }}$ century occupation of the site.

Table 1. Archaeological materials from 41MR254.

Artifact Class

Aboriginal artifacts

ceramic vessel sherd

chert lithic debris

European or American metal goods

cast iron kettle pieces

iron cut nail

lead bullet

iron flintlock side plate

iron frizzen spring

iron point

brass/copper strip

iron strap, modified

brass kettle strip

iron wire, one possibly modified

iron buckle

horse bridle piece

plain metal button

shotgun shell
No. 


\section{Aboriginal Artifacts}

Three pieces of chert lithic debris (gray, $n=2$, and brown, $n=1$ ) are in the collection, having been recovered in Units 1 and 3 . The brown chert piece has an area of smoothed cortex on it; the gray chert pieces are non-cortical. If these materials are associated with the early $19^{\text {th }}$ century occupation of the site, this would suggest that traditional lithic knapping activities - perhaps the manufacture of flake tools or scraping implements-were an aspect of that occupation.

The 16 aboriginal sherds include 12 sherds from the unit excavations (Unit 1 , $\mathrm{n}=1$; Unit 2, n=2; and Unit 3, n=9) and four from the exploration of metal detector hits. The location of these latter sherds among the metal detector hits is not known.

Four of the aboriginal ceramic sherds are decorated, three with parallel brushing marks and a fourth with a single straight incised line (Table 2 ). All four have a relatively fine sandy paste, but only one has an added temper (grog from crushed fired clay or crushed sherds). The co-association of a sandy paste ceramic ware and brushed decorations on the ceramic vessel body is consistent with Coushatta ceramics from early $19^{\text {th }}$ century East Texas and Red River Louisiana sites (Jurney and Perttula 1995:21, 23, 25; Perttula 1994:73). Brushed Caddo pottery from this same part of northeastern Texas almost always has temper added to the paste - usually a clay or silty paste, not sandy paste-particularly grog or grog-bone tempering. The brushed sandy paste pottery from 41MR254 appears to be from Chattahoochee Roughened, var. Chattahoochee jars. This is a pottery type defined from historic Creek sites in Alabama (see Knight 1987:201). These jars were used in the preparation of corn foods, especially sofkee, a hominy stew flavored with venison. This is the most common pottery type on local Coushatta sites (Jurney and Perttula 1995: Table 5). The one incised sherd is probably from a carinated bowl or flared-rim bowl.

Table 2. Temper and thickness of the decorated and plain aboriginal sherds.

\begin{tabular}{lllllll}
\hline Sherd type & N & \multicolumn{5}{c}{ Paste and temper } \\
& & SP* & $\mathrm{g} / \mathrm{SP}$ & $\mathrm{g}$ & shell & mean thickness (mm) \\
\hline $\begin{array}{l}\text { Decorated } \\
\text { parallel brushed } \\
\text { straight line incised }\end{array}$ & 3 & 2 & 1 & - & - & 5.27 \\
$\begin{array}{l}\text { Plain } \\
\text { body sherd }\end{array}$ & 11 & 1 & - & - & - & 5.10 \\
$\begin{array}{l}\text { base sherd } \\
\text { Totals }\end{array}$ & 1 & - & - & 1 & - & 5.58 \\
\hline & 16 & 11 & 2 & 2 & 1 & 7.30 \\
\hline
\end{tabular}

*SP=sandy paste; $\mathrm{g}=\mathrm{grog}$ 
Seventy-five percent of the plain body and base sherds (the one base is diskshaped and $85 \mathrm{~mm}$ in diameter) also have a sandy paste, and one of these also has an added grog temper (see Table 2). Two others are grog tempered (and have a clay paste), and one has leached or fugitive shell tempering. Shell tempered vessels are present in other Coushatta ceramic assemblages, but not in great quantities: $7 \%$ of the sherds at the Carl Matthews site (41PK2), occupied by the Coushatta between ca. 1820-1835, are tempered with shell (Jurney and Perttula 1995: Table 3).

The Coushatta sherds from 41MR254 are from thin (5.1-5.58 mm thickness range on body sherds) and well-made vessels. Breakage of the sherds suggests they were coilmanufactured.

More than $62 \%$ of the aboriginal sherds from $41 \mathrm{MR} 254$ are from vessels that have been fired in a reducing or low oxygen environment, probably because the vessels were smothered in coals in a fire (Table 3 ). These sherds have a dark gray color on one or both vessel surfaces. The remaining sherds are from vessels fired in an oxidizing or high oxygen environment (probably resting above the fire, and pulled from the fire to cool), or incompletely oxidized, leaving them with a light surface color (in some few cases, with an orangish tint) on either both or one vessel surface.

Table 3. Firing conditions of the aboriginal sherds.

\begin{tabular}{lllll}
\hline Sherd type & \multicolumn{3}{c}{ Firing Conditions } \\
& Oxidizing & Incompletely Oxidized & Reducing & $\begin{array}{c}\text { Reducing, but cooled } \\
\text { in Oxidizing environment }\end{array}$ \\
\hline $\begin{array}{llll}\text { Decorated } \\
\text { Plain }\end{array}$ & - & $50.0^{*}$ & 25.0 & 25.0 \\
\hline & 25.0 & 8.3 & 33.3 & 31.3 \\
\hline Totals & 18.8 & 18.8 & 31.3 & \\
\hline *percentage & & & &
\end{tabular}

\section{Historic European or American Metal Goods}

Approximately $37 \%$ of the historic European or American metal goods from $41 \mathrm{MR} 254$ are iron cut nails (Figure 3) of several different sizes. According to Wells (2000: Figure 8), these kind of nails were manufactured in the U.S. after 1820 . The cut nails were concentrated in the central and eastern part of the site, probably in the area of a log cabin (see Figure 2). 


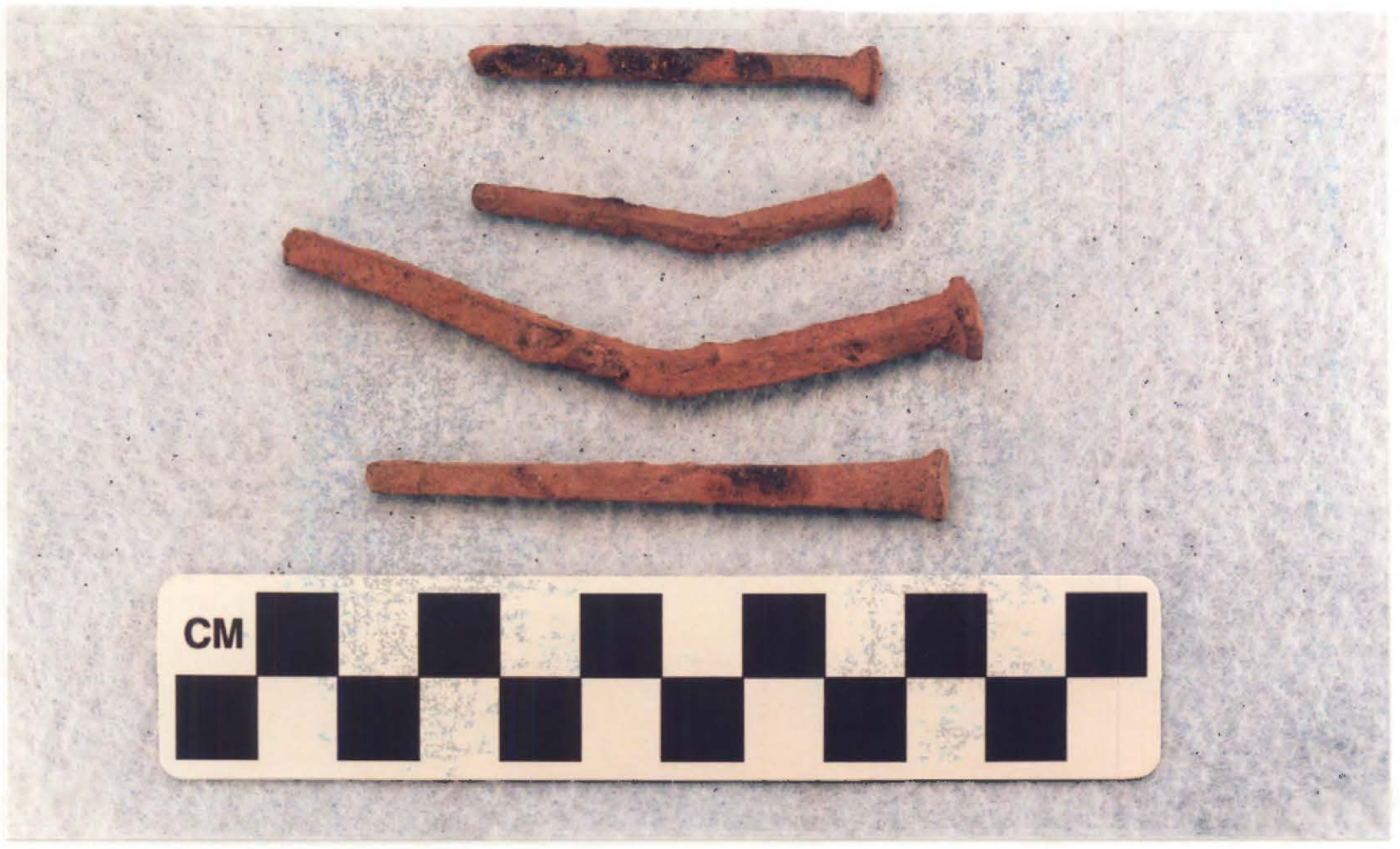

Figure 3. Cut nails from 41MR254.

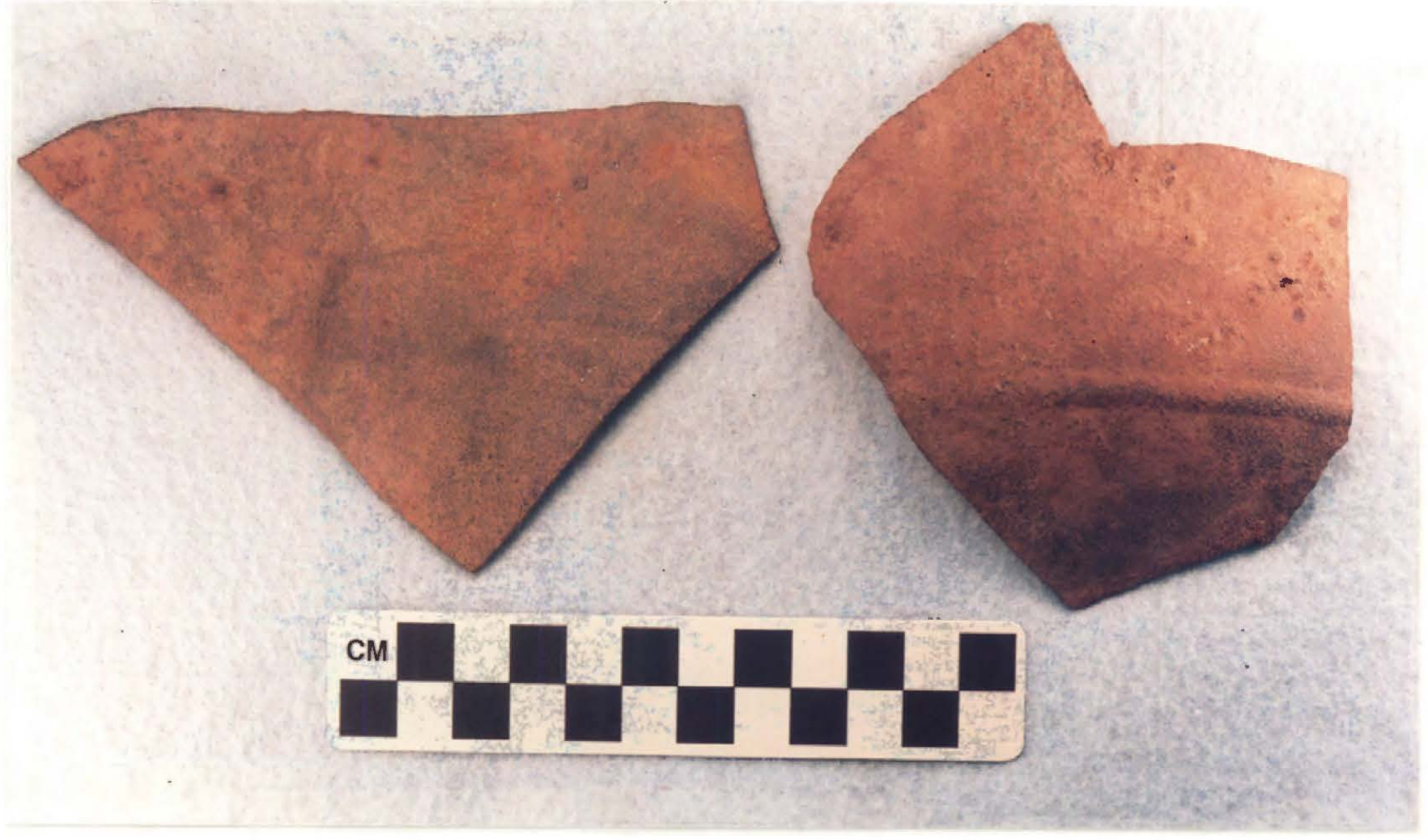

Figure 4. Cast iron kettle pieces from 41MR254. 
Also common among the metal goods are four pieces of cast iron, probably from 3-legged trade kettles (Figure 4). The cast iron kettle pieces are 3.3-3.8 mm thick. These cast iron kettles are ubiquitous on late $18^{\text {th }}$ and early $19^{\text {th }}$ century aboriginal sites in the region, and they were probably obtained from American trading posts or factories (McCrocklin 1990: Figure 14, 1992; Parsons et al. 2002:59-61; Perttula 1994:72-73).

Less functionally obvious metal goods recovered from the metal detecting include a brass or cuprous strip (1.4 mm thick) or band with two drilled holes, a thin $(2.0 \mathrm{~mm})$ iron strap (Figure 5) that appears to have been shaped or ground down to a narrow tip along one edge, and two pieces of iron wire, one probably altered from use since it has a blunted end. There is one piece ( $1.3 \mathrm{~mm}$ thick) of sheet brass (Figure 6a), probably part of a patch cut from a brass kettle (cf. Parsons et al. 2002:62). The metal detecting also found a badly eroded but apparently plain back and face iron button ( $17 \mathrm{~mm}$ in diameter) from the far western part of the site (see Figure 2).

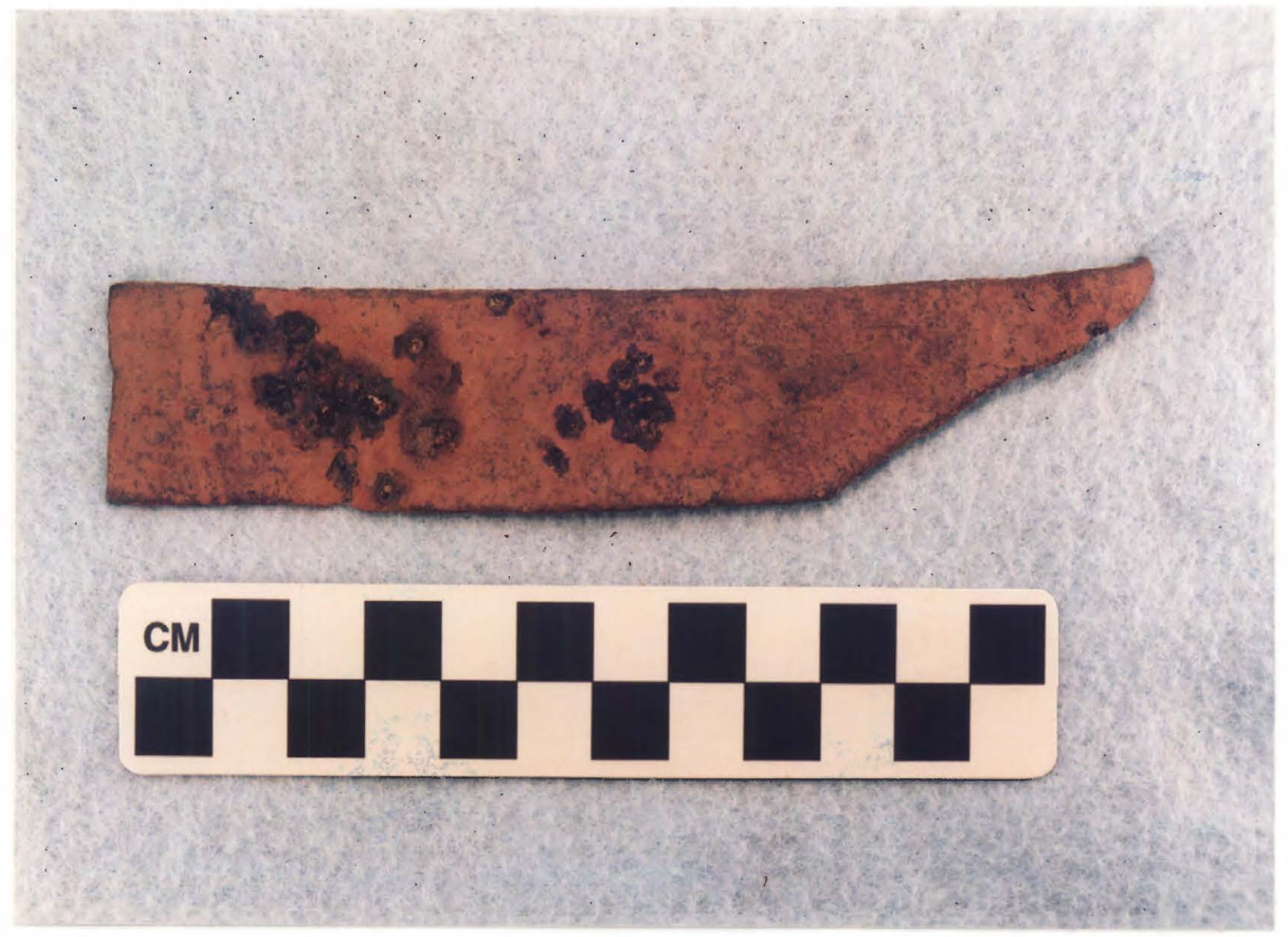

Figure 5. Iron strap from 41MR254. 


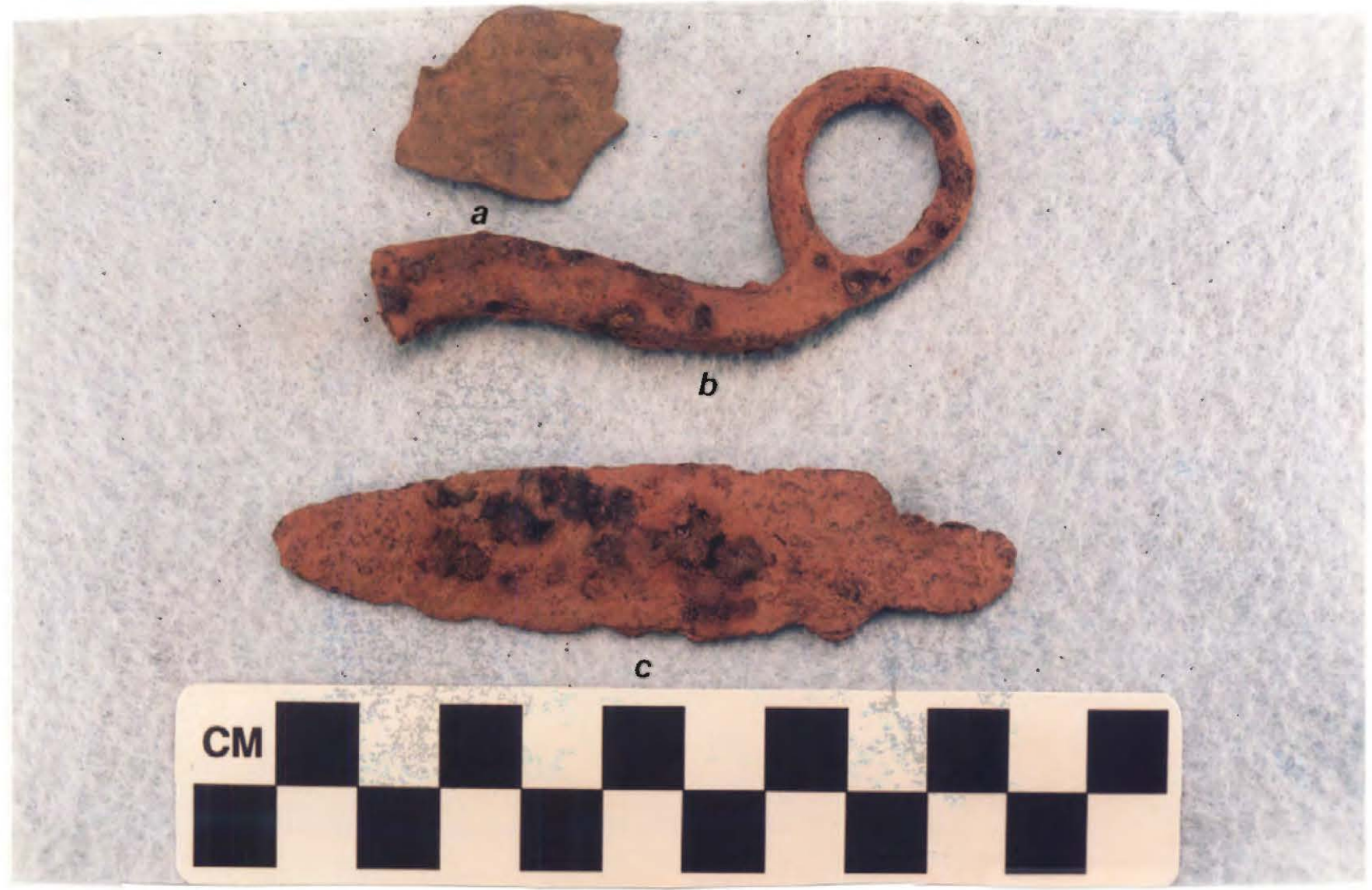

Figure 6. Other metal goods; a, sheet brass; b, bridle bit; c, iron point.

A horse bridle part, probably a partial piece from a bridle bit branch with a loop at one end (Figure 6b), came from near Unit 3 (see Figure 2). Jay Blaine (April 14, 2007 personal communication to the senior author) suggests that based on the style of this bridle fragment, it may date to after ca. 1860. McCrocklin (1990: Figure 15) does illustrate a similar but larger bridle bit piece with a cheek plate from 16BO207, an early $19^{\text {th }}$ century Red River Louisiana Coushatta village.

A thin iron point, found a few meters north of Unit 2 (see Figure 2), is also in the $41 \mathrm{MR} 254$ metal goods. It was likely made from a thin $(2.4 \mathrm{~mm})$ piece of barrel hoop scrap or less likely from a knife blade (Figure $6 \mathrm{c}$ ). It has filed edges and a small rectangular stem, and measures $91 \mathrm{~mm}$ in total length, $21 \mathrm{~mm}$ in maximum width on the point blade, and the stem is $11 \mathrm{~mm}$ wide and $16 \mathrm{~mm}$ in length. Similar iron points have been recovered from a ca. 1820-1835 Coushatta site in southeastern Texas (see Perttula 1994: Figure 3m).

The iron buckle (Figure 7) came from the same metal detector find spot as the one metal button (see Figure 2). The buckle is the appropriate size (52 $\mathrm{mm}$ or 2 inches in length) and shape for a pant and vest buckle. This type of buckle was apparently patented in 1855 (Davidson 2006:179, 181 and Figures 114-115). If this identification is chronologically or typologically accurate, this particular metal artifact would appear to be younger than much of the other metal goods from the site. According to Davidson 
(2006:179), these slide buckles were used "on a cinch belt to cinch the waist of either garment [a vest or a pair of pants] so as to obtain a snug and better fit."

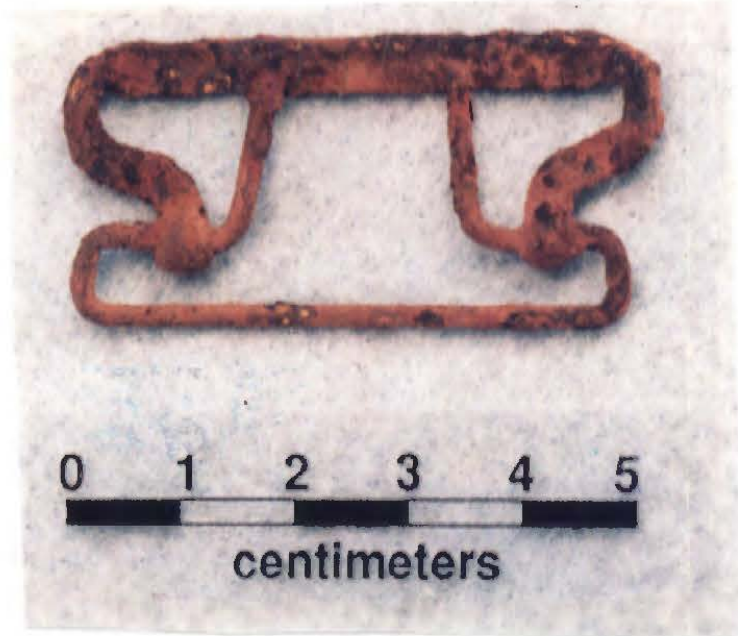

Figure 7. Iron slide buckle from a metal detector hit at 41MR254.

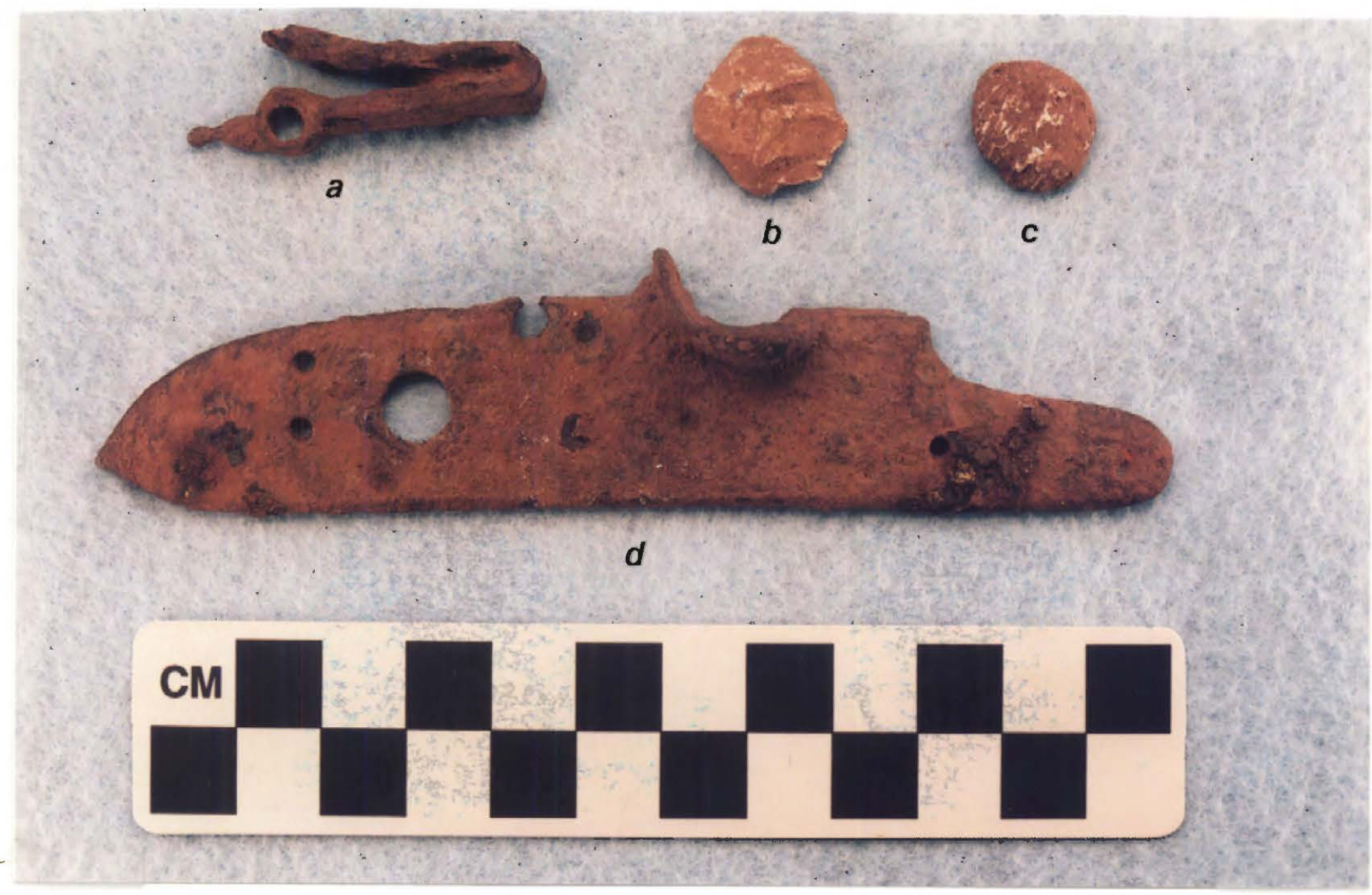

Figure 8. Firearms-related artifacts: a, frizzen spring; b-c, lead balls; d, lock plate. 
The remainder of the metal goods from 4IMR254 are firearms-related. This includes two spent lead bullets ( $16-19 \mathrm{~mm}$ wide; one has scraping and cut marks on it) from rifles (Figure 8b-c). One was found north of Unit 3 (see Figure 2). There is also a frizzen spring (Figure $8 \mathrm{a}$ ), $43 \mathrm{~mm}$ in length. The pistol to rifle-sized frizzen spring came from a metal detector hit between Units I and 3 (see Figure 2). An iron lock plate (127 $\mathrm{mm}$ in length and $3.8 \mathrm{~mm}$ in thickness) from a flint lock rifle (Figure 8d) was found in the immediate vicinity of Unit 1 (see Figure 2). McCrocklin (1990: Figure 10) illustrates virtually identical lock plates from a number of Louisiana Red River Coushatta settlements. Blaine (April 14, 2007 personal communication) suggests that an 1830s age for this lock plate would be a reasonably confident assessment.

\section{CONCLUSIONS}

The archaeological information obtained from very limited investigations (metal detecting and three $1 \times 1 \mathrm{~m}$ units) in 2002 at 41MR254 strongly suggest that this is the location of a pre-1840 Coushatta Indian village on Big Cypress Bayou. This site is only one of a very few early $19^{\text {th }}$ century Coushatta settlements known in all of Northeast Texas, and as such has the potential to shed considerable light on the life and times of Coushatta Indian peoples during a tumultuous period for Indians, the period of the establishment of the Republic of Texas.

The best evidence of this pre-1840 Coushatta occupation derives from the aboriginal ceramic vessel sherds found there, as the ceramics seem to share characteristics of paste, temper, and decoration with other early $19^{\text {th }}$ century Coushatta sites in northwest Louisiana and East Texas (McCrocklin 1990; Jurney and Perttula 1995; Perttula 1994). The most diagnostic ceramic decorative style documented in early $19^{\text {th }}$ century Coushatta ceramics - namely appliqued fillets placed in a horizontal band below the rim of Chattahoochee Roughened everted rim jars-is not present at 41MR254, however, but the aboriginal sherd assemblage is quite small.

The metal goods, for the most part, are also consistent with an early $19^{\text {th }}$ century occupation, and one that is likely aboriginal in nature. The archaeological evidence is this assertion are pieces of iron that appear to have been reworked as tools, along with an iron arrow point made from barrel hoop scrap and brass kettle scraps from the recycling of a brass kettle. The occupants of 41MR254 apparently had access to American or European metal tools and goods (among them a flintlock rifle), and they used and reworked the metal to suit their own purposes. When the metal goods no longer served a useful purpose or were broken, they were readily discarded as trash, probably because they could be easily replaced. The recovery of iron cut nails that were manufactured beginning after 1820 suggests that this probable Coushatta Indian occupation began sometime after 1820 , and would have ended by ca. 1840, when all aboriginal groups, including the Caddo, were forced to leave northeastern Texas.

Not all the metal goods recovered at 41MR254 appear to be a product of an occupation that would have ended by ca. 1840 . The slide buckle and bridle bit appear to be younger than that, and their recovery in the metal detecting leaves open the question of 
how they ended up at the site, and is there a more substantial post-1840 and AngloAmerican occupation here that has not yet been detected in the limited archaeological investigations? This is a question that can only be resolved with further work at the site.

Hopefully, further archaeological investigations can be conducted at 4 I MR254 to obtain additional evidence bearing on the ethnic affiliation and age of the $19^{\text {th }}$ century material culture remains found there. It is also important to identify other components of the site, because if it is truly a Coushatta Indian village, then there must be other domestic locales that can be identified besides the small occupation area at 4IMR254; the present extent of the site suggests it is the product of a single household, probably occupied for no more than 10-20 years. Further archaeological investigations at 41 MR254 could include additional metal detecting, along with extensive shovel testing to locate other habitation deposits, and controlled excavations in productive habitation deposits. Such controlled excavations provide the best opportunity to obtain a representative sample of the material culture remains discarded at $41 \mathrm{MR} 254$, especially the recovery of a larger sample of aboriginal ceramic vessel sherds. Such sherds can be subjected to thermoluminescence dating to establish the absolute age of the vessel that the sherd came from - which could provide incontrovertible evidence that the site was occupied in the early $19^{\text {th }}$ century by the Coushatta, as would the recovery of diagnostic Chattahoochee Roughened jar sherds with appliqued fillet designs in a larger ceramic assemblage. Lastly, controlled excavations may encounter architectural (wattle and daub covered structures) and pit features (i.e., smudge pits and outdoor earth ovens and cooking pits) preserved at the site like those documented at other Coushatta sites (see McCrocklin 1990; Jurney and Perttula I995) that would shed light on the ethnic affiliation of the early $19^{\text {th }}$ century occupation.

\section{ACKNOWLEDGMENTS}

Bo Nelson took the photographs used in this article, and Sandy Hannum prepared Figures 1 and 2. Thanks also to Jay Blaine for looking at xeroxes of selected metal artifacts from the site, and offering sage comments on their likely function and age.

\section{REFERENCES CITED}

Bagur, J. D.

2001 A History of Navigation on Cypress Bayou and the Lakes. University of North Texas Press, Denton.

Davidson, J. M.

2006 Material Culture, Chronology, and Socioeconomics. In Two Historic Cemeteries in Crawford County, Arkansas, edited by R. C. Mainfort, Jr. and J. M. Davidson, pp. 97-218. Research Series No. 62. Arkansas Archeological Survey, Fayetteville. 
General Land Office

1941 Texas Land Title Abstracts, Volume 1-A: A report from a Portion of Volume 1, Abstract of all original Texas Land titles Comprising Grants \& Locations to August 31, 194I Originally Comprised by the General Land Office, Austin, Texas when Bascom Giles was Commissioner. Reprinted by The Wright Press, Paris, Texas.

Jurney, D. H. and T. K. Perttula

1995 Nineteenth-Century Alibamu-Koasati Pottery Assemblages and Culinary Traditions. Southeastern Archaeology 14(1):17-30.

Knight, V. J.

1987 Tukabatchee: Archaeological Investigations at an Historic Creek Town, Elmore County, Alabama, 1984. Report of Investigations 45. Office of Archaeological Research, Alabama State Museum of Natural History, University of Alabama, Tuscaloosa.

McCrocklin, C.

1990 The Red River Coushatta Villages of Northwest Louisiana 1790-1835. Louisiana Archaeology 12:129-178.

1992 Three Historic Sites on Red River. Arkansas Archeologist 31:31-63.

Parsons, M. L., J. E. Bruseth, J. Bagur, S. E. Goldborer, and C. McCrocklin

2002 Finding Sha' chahdinnih (Timber Hill): The Last Village of the Kadohadacho in the Caddo Homeland. Archeological Reports Series No. 3. Texas Historical Commission, Austin.

Perttula, T. K.

1994 Material Culture of the Koasati Indians of Texas. Historical Archaeology 28(1):65-77.

Wells, T.

2000 Nail Chronology: The Use of Technologically Derived Features. In Approaches to Material Culture Research for Historical Archaeologists, compiled by D. R. Brauner, pp. 318-339. $2^{\text {nd }}$ Edition. The Society for Historical Archaeology, California, Pennsylvania. 